\title{
Influence of Cytosolic Malic Enzyme in Oleaginous Yeast Rhodotorula mucilaginosa IIPL32 for Lipid Biosynthesis
}

\author{
Sheetal Bandhu ${ }^{1,2}$, Tripti Sharma1, Deepti Agrawal' ${ }^{1,2}$, Debashish Ghosh ${ }^{1,2}$, Dilip K Adhikari ${ }^{1,2}$ and Diptarka Dasgupta $^{1,2^{\star}}$ \\ ${ }^{1}$ Biotechnology Conversion Area, Biofuels Division, CSIR-Indian Institute of Petroleum, Mohkampur, Dehradun, Uttarakhand, India \\ ${ }^{2}$ Academy of Scientific and Innovative Research (AcSIR), Chennai, Tamil Nadu 600113, India
}

\begin{abstract}
A cytosolic $\mathrm{NADP}^{+}$dependent malic enzyme has been purified and characterized from an oleaginous yeast Rhodotorula mucilaginosa IIPL32 to investigate its role in lipid biosynthesis. The enzyme has selective and high affinity for NADP and L-malate. Sesamol, a nonoil component of sesame seed oil, has been used during nitrogen depleted condition to evaluate inhibition of malic enzyme and lipid production. Sesamol did not inhibit purified malic enzyme. Sesamol was converted into catechol like metabolite to impart enzyme inhibition and thus lipid production by decreased supply of NADPH ${ }^{+}$.
\end{abstract}

Keywords: Malic enzyme; Oleaginous yeast; Purification; Lipid; Sesamol

\section{Introduction}

Microbial single cell oil has been visualized as an alternative to plant based natural fatty oils as feedstocks for biofuels or oleochemicals, owing to its short generation time, low space requirement and product uniformity independent of climate and geography. Oleaginous yeasts are advantageous over oil bearing microalgae, as the former could be harvested for lipid synthesis using cheap carbon sources under controlled conditions with higher productivity, against the latter, which depends on atmospheric $\mathrm{CO}_{2}$ as carbon source with less productivity [1]. Yeast lipid is generally quantified in two ways; first, percentage lipid with respect to dry cell mass and second, amount of lipid generated by conversion of sugar. Latter represents more realistic real time features, based on yield and economics. Theoretically, sugar to lipid conversion is maximum $33 \%$ however; practically $20-22 \%$ conversion has been achieved in oleaginous yeasts [2]. Lipid biosynthesis in yeast occurs in cytosol under nitrogen limiting condition, with acetyl CoA as the initiating unit and $\mathrm{NADPH}^{+}$as reducing equivalent [3]. Requisite $\mathrm{NADPH}^{+}$is generated by the pentose phosphate pathway (PPP) and $\mathrm{NADP}^{+}$dependent cytosolic Malic Enzyme (ME). Cytosolic ME activity has been reported to alter proportionally during lipid accumulation phase suggesting its crucial role in fatty acid biosynthesis [4]. $\mathrm{NADPH}^{+}$ supply in absence of cytosolic ME in oleaginous yeasts like Yarrowia lipolytica and Lipomyces starkeyi is met by PPP, however, in M. alpina supply of reluctant is met by both $[2,5,6]$. This is further supported from the stoichiometry of fatty acid synthesis as the lipid yield would be less, in absence of cytosolic ME when PPP was the sole $\mathrm{NADPH}^{+}$ provider. Rhodotorula sp. are reported as promising oleaginous yeast, to generate intracellular lipid body from low cost renewable feedstock derived pentose and hexose sugars. In this paper, we have evaluated the presence and role of cytosolic ME in Rhodotorula mucilagenosa IIPL32, as a supplier of NADPH for lipid biosynthesis. The enzyme was purified and characterized to confirm its affinity towards L-malate and NADP ${ }^{+}$. Effects of selective inhibitors were also correlated to enzyme activity and lipid production.

\section{Experimental Methodologies}

\section{Materials and microorganism}

Lignocellulosic hydrolysate (xylose rich) was generated in Biotechnology Conversion Area (CSIR-IIP) as per our earlier report [7].
Standards for lower carbon chain fatty acids (C6:0 to C14:0) palmitic acid (C16:0), palmitoleic acid (C16:1), stearic acid (C18:0), oleic acid (C18:1), linoleic acid (C18:2), linolenic acid (C18:3) and Sesamol, catechol and other inhibitors were procured from Sigma and were of analytical grade. All other chemicals and reagents were bought locally and were either of analytical or commercial grades.

Rhodotorula mucilaginosa IIPL32 (RMIIPL32), isolated from soil of oil dumping shed in CSIR-Indian Institute of Petroleum, Dehradun and optimally grown at $32^{\circ} \mathrm{C}$, was used as oleaginous yeast for this experimental study. Cell biomass generation, lipid accumulation and ME activity were conducted in a designed medium (composition in $\mathrm{g} / \mathrm{L}$; xylose rich lignocellulosic biomass hydrolysate, adjusted to 20.0 ; $\left(\mathrm{NH}_{4}\right)_{2} \mathrm{SO}_{4}, 1.98 ; \mathrm{KH}_{2} \mathrm{PO}_{4}, 1.26 ; \mathrm{Na}_{2} \mathrm{HPO}_{4}, 0.748 ; \mathrm{MgSO}_{4}, 0.7 ; \mathrm{CaCl}_{2}$, $0.05 ; \mathrm{MnSO}_{4}, 0.005 ; \mathrm{H}_{3} \mathrm{BO}_{3}, 0.005 ; \mathrm{CoNO} 3,0.005 ; \mathrm{NH}_{4} \mathrm{MoO}_{4}, 0.005$; yeast extract 1.0; $\mathrm{pH}$ 4.5-5.0). Taxonomic characterization of the yeast was done based on partial nucleotide sequence of $18 \mathrm{~S}$ rDNA gene, amplified using forward (5' ACCCGCTGAACTTAAGC3') and reverse (5'CCGTGTTTCAAGACGGG3') primers with genomic DNA as template. Amplified DNA was sequenced via paired end (PE) DNA sequencing method and aligned (BLASTN) with submitted sequences available in NCBI database to classify the isolate as R. mucilaginosa (Gen Bank accession number KF313359; MTCC 25056) (Figure 1).

\section{Quantitative estimation of lipid and ME}

Cell biomass generation, lipid accumulation and ME production were accomplished in $15 \mathrm{~L}$ fermenter (BioSac, India; working volume of $12 \mathrm{~L}$ equipped with automated control and SCADA) at $32^{\circ} \mathrm{C}$ and $\mathrm{pH}$ 4.5. An initial growth phase of $24 \mathrm{~h}$ (consumption of $90 \%$ pentose sugar) was followed by maturation phase where the carbon-to-nitrogen $(\mathrm{C} / \mathrm{N})$ ratio in the broth was increased by pumping of concentrated pentose

*Corresponding authors: Diptarka Dasgupta, Biotechnology Conversion Area, Biofuels Division, CSIR-Indian Institute of Petroleum, Mohkampur, Dehradun, Uttarakhand, India, Tel: +91 135 2525763; E-mail: ddgupta@iip.res.in

Received March 20, 2017; Accepted March 31, 2017; Published April 11, 2017

Citation: Bandhu S, Sharma T, Agrawal D, Ghosh D, Adhikari DK, et al (2017) Influence of Cytosolic Malic Enzyme in Oleaginous Yeast Rhodotorula mucilaginosa IIPL32 for Lipid Biosynthesis. J Bioanal Biomed 9: 100-106. doi:10.4172/1948-593X.1000161

Copyright: @ 2017 Bandhu S, et al. This is an open-access article distributed under the terms of the Creative Commons Attribution License, which permits unrestricted use, distribution, and reproduction in any medium, provided the original author and source are credited. 


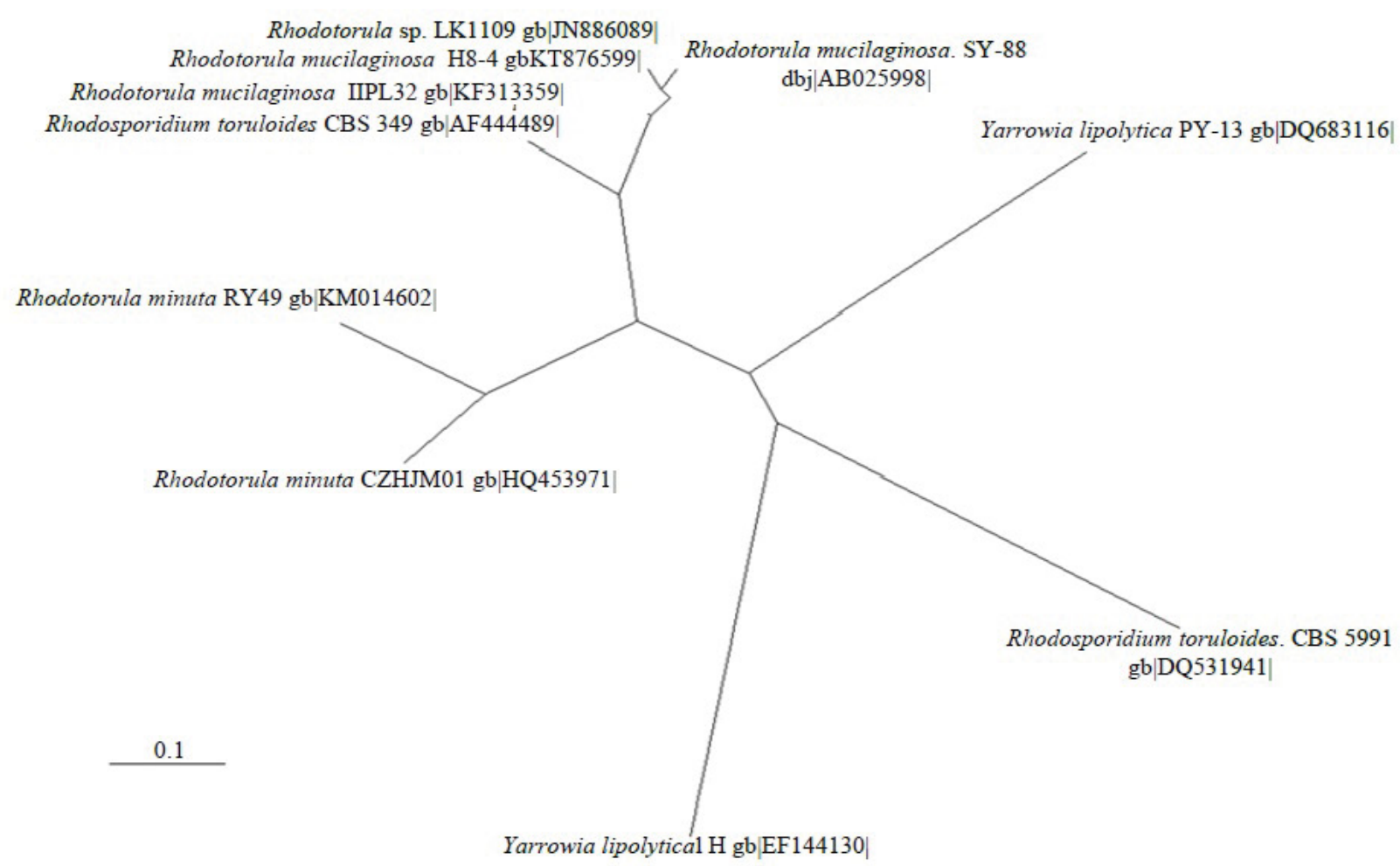

Figure 1: Phylogenetic dendrogram, indicating the position and distance matrix based comparison of the oleaginous yeast Rhodotorula mucilaginosa IIPL32 (Gen Bank accession number KF313359). The numbers in bracket indicate accession number of the organisms.

sugar solution. During maturation phase, cell biomass was harvested after $80 \%$ consumption of sugar to recover lipid and ME from $R$. mucilagenosa (henceforth designated as $\mathrm{RM}_{M E}$ ).

Lipid rich cells were collected by gravity settling and oven dried $\left(60^{\circ} \mathrm{C}\right)$. Lipid was gravimetrically extracted with chloroform $\left(\mathrm{CHCl}_{3}\right)$ and methanol $\left(\mathrm{CH}_{3} \mathrm{OH}\right)$ in a $2: 1$ ratio as solvent system. Fatty acid compositions were profiled in multidimensional GC (Agilent, USA) after transesterification with $\mathrm{BF}_{3}$ as described by Patel et al. with certain modifications [8].

To determine $\mathrm{RM}_{M E}$ activity, cell pellet was washed with deionized water and resuspended in lysis buffer $(50 \mathrm{mM}$ triethanolamine- $\mathrm{HCl}, \mathrm{pH}$ 7.4, $1 \mathrm{mM}$ EDTA, 20\% w/v glycerol, $1 \mathrm{mM}$ dithiothreitol) for disruption in high pressure homogenizer (Panda Plus 2000, Gea) with continuous recycling for $30 \mathrm{~min}$. $\mathrm{RM}_{M E}$ activities were estimated as per Qiguo et al. with minor modifications using a U2900 UV-Vis spectrophotometer (Hitachi, Japan) for $5 \mathrm{~min}$ at $340 \mathrm{~nm}$ after $1 \mathrm{~min}$ delay time to nullify endogenous reduction of $0.3 \mathrm{mM}$ NADP [9]. NADPH (extinction coefficient $6.22 \times 10^{3} \mathrm{~L} / \mathrm{M} / \mathrm{cm}$ ) generation was measured as variance in absorbance for a defined time span. Reaction mix contained $66.6 \mathrm{mM}$ triethanolamine $\mathrm{HCl}$ buffer, $5 \mathrm{mM} \mathrm{MnCl}, 3.33 \mathrm{mM}$ malate, and 0.33 mM NADP apart from enzyme solution. Each activity determination was made in triplicate sets with standard deviations not exceeding $5 \%$. Enzyme activity was also determined by replacing NADP with NAD to confirm its cytosolic presence. One unit of ME activity was defined as the amount of enzyme required to catalyze the formation of $1 \mu \mathrm{mol}$ of $\mathrm{NADPH}^{+}$per min under specified conditions. Total protein was determined by the method of Bradford with bovine serum albumin as standard [10].

\section{Effect of sesamol on of malic enzyme and lipid production}

Sesamol, a nonoil component of sesame seed oil was reported to inhibit ME activity and affect lipid production. After cell biomass generation in fermenter, sesamol $(0 \mathrm{mM}, 5 \mathrm{mM}$ and $10 \mathrm{mM})$ and catechol $(10 \mathrm{mM})$ were separately added along with concentrated sugar solution (biomass prehydrolysate to enhance $\mathrm{C} / \mathrm{N}$ ratio for lipid accumulation). Batches were terminated after $24 \mathrm{~h}$ and in between intracellular lipid contents and ME activity were measured in every $6 \mathrm{~h}$ interval as described.

\section{Purification of malic enzyme}

$\mathrm{RM}_{M E}$ was purified to homogeneity in two steps. Entire purification procedure was carried out at $4^{\circ} \mathrm{C}$ unless indicated otherwise. Crude enzyme extract was loaded in a MacroSep High S (Bio-Rad, USA) cation exchange column $(20 \times 1.85 \mathrm{~cm})$ pre-equilibrated with $10 \mathrm{mM}$ Tris- $\mathrm{HCl}$ buffer containing $2 \mathrm{mM} \beta$-mercaptoethanol and $10 \%$ glycerol ( $\mathrm{pH} 7.4$ ). The column was eluted $(1 \mathrm{ml} / \mathrm{min})$ with same buffer until absorbance of effluent $\left(\lambda_{280}\right)$ became zero. Each fraction of $2 \mathrm{~mL}$ was collected and those with high specific activity were pooled and lyophilized. Lyophilized powder was re-dissolved in minimum volume of same buffer solution and was passed through pre-equilibrated adenosine 2'5'-bisphosphate agarose (Sigma-Aldrich, USA) column $(5.0 \times 0.70$ $\mathrm{cm})$. Column was then washed until $\lambda_{280} \mathrm{~nm}$ of effluent reached zero. Bound proteins were eluted by NADP gradient $(0-100 \mu \mathrm{M})$ in same 
buffer. Fractions were collected at a flow rate of $20 \mathrm{~mL} / \mathrm{h}$ and active fractions were pooled [11]. Purified protein migrated as single band in gel electrophoresis and was activity stained against $5 \%$ acetic acid after $2 \mathrm{~h}$ immersion into a solution of $55 \mathrm{mM}$ triethanolamine- $\mathrm{HCl}$ buffer (pH 7.4), $0.47 \mathrm{mM}$ NADP, $17.2 \mathrm{mML}$-malate, $2.75 \mathrm{mM} \mathrm{MnC12,} 0.55 \mathrm{mg} /$ $\mathrm{ml}$ nitrobluetetrazolium and $0.097 \mathrm{mg} / \mathrm{ml}$ phenazinemethosulfate [11].

\section{Enzyme characterization}

$\mathrm{RM}_{M E}$ was characterized to identify its kinetics parameters, role of divalent cations and effect of inhibitors to correlate its role in lipid accumulation. In vitro characterizations were performed under optimum $\mathrm{pH}$ and temperature.

Influence of $\mathrm{pH}$ on $\mathrm{RM}_{M E}$ activity was determined within $\mathrm{pH}$ ranges of $4.0-9.0$ by adjusting reaction mixture with $66.6 \mathrm{mM}$ of various buffer solutions, viz. N-methyl piperazine ( $\mathrm{pH} 4.0-5.5)$, piperazine ( $\mathrm{pH}$ 6.0-6.5), and triethanolamine- $\mathrm{HCl}(\mathrm{pH} 7.0-9.0)$. Enzyme activity was quantified as mentioned earlier. Thermostability of $\mathrm{RM}_{M E}$ was investigated by pre-incubating enzyme solutions at $15-55^{\circ} \mathrm{C}$ for $90 \mathrm{~min}$. After $15 \mathrm{~min}$ interval, residual activities were quantified as per protocol mentioned and compared with non-pre-incubated sample. Each enzyme activity was quantified in triplicates and further characterizations were performed under optimized $\mathrm{pH}$ and temperature.

Initial reaction rate for NADP reduction was calculated by estimating $\mathrm{RM}_{M E}$ activity at different malate $(0.25$ to $5.0 \mathrm{mM})$ and NADP $(0.025$ to $0.5 \mathrm{mM})$ concentrations. Michaelis Menten constant $\left(\mathrm{K}_{m}\right)$ and rate of reaction $\left(\mathrm{V}_{\max }\right)$ were determined by Lineweaver and Burk plot [12]. Effect of various metal ions was investigated by quantifying $\mathrm{RM}_{M E}$ activity with $5 \mathrm{mM}$ metal salts of $\mathrm{Mn}^{2+}, \mathrm{Ca}^{2+}, \mathrm{Fe}^{3+}$, $\mathrm{Fe}^{2+}, \mathrm{Co}^{2+}, \mathrm{Cu}^{2+}, \mathrm{Mg}^{2+}, \mathrm{Zn}^{2+}$, and $\mathrm{Ni}^{2+}$. Enzyme activity quantified in absence of metal salt was considered as $100 \%$ and residual activity was determined accordingly. To study the effect of inhibitors, $\mathrm{RM}_{M E}$ was incubated for $15 \mathrm{~min}$ in $66.6 \mathrm{mM}$ triethanolamine- $\mathrm{HCl}$ buffer ( $\mathrm{pH} 7.4$ ) with inhibitors (EDTA, idoacetamide, tosylphenylalanyl chloromethyl ketone (TPCK), 4-chloromercurobenzoic acid, Phenyl Methane Sulfonyl Fluoride (PMSF), phenylglyoxal hydrate and pepstatin A, sesamol and catechol at a final concentration of $1 \mathrm{mM}$. Residual enzyme activity was determined in same way as stated before and activity without any inhibitor was considered $100 \%$.

\section{Analytical techniques}

Residual xylose in biomass hydrolysate during yeast growth and lipid maturation were quantitatively analyzed with HPLC (UFLC, Shimadzu, Japan) with PL Hiplex-H acid $8 \mu \mathrm{m}$ column $(100 \times 7.7 \mathrm{~mm}$ diameter, by PL Polymer laboratory, UK) using a Refractive Index (RI) detector. Column was eluted with a mobile phase of $1 \mathrm{mM}$ sulfuric acid at a flow rate of $0.7 \mathrm{ml} / \mathrm{min}$ and oven temperature was maintained at $70^{\circ} \mathrm{C}$.

Total nitrogen was analysed in TN 3000 Total Nitrogen Analyzer (Thermo Fisher, USA) as per ASTM D 4629.

Dry cell mass was determined with known quantity of cellular broth $(1 \mathrm{ml})$ by hot air drying of cell pellets in microfuges. Average of triplicate data was considered for dry cell mass determination.

Qualitative multi-dimensional gas chromatograph analyses (GC $\times$ GC) were performed for transesterified lipid with Agilent 7890B GC (California, United States) fitted with a thermal modulator assembly, FID and three different capillary columns (PAC Analytical, Canada) $\left(1^{\text {st }}\right.$ dimension non-polar, $30 \mathrm{~m} \times 250 \mu \mathrm{m} \times 0.25 \mu \mathrm{m} ; 2^{\text {nd }}$ dimension midpolar, $10 \mathrm{~m} \times 320 \mu \mathrm{m} \times 0.25 \mu \mathrm{m}$ and bleed column, $4.7 \mathrm{~m} \times 100 \mu \mathrm{m} \times$
$0.25 \mu \mathrm{m})$ connected serially with thermal modulator. Oven temperature was programmed from $40^{\circ} \mathrm{C}$ ( 7 min holdup) to $270^{\circ} \mathrm{C}$ ( 20 min holdup) with different ramping rates. Helium was used as a carrier gas under constant flow $(0.8 \mathrm{ml} / \mathrm{min})$ mode. All samples were analyzed in splitless mode (100:1) at an injection temperature of $250^{\circ} \mathrm{C}$. $0.4 \mu \mathrm{L}$ injection of samples was performed with a $10 \mu \mathrm{L}$ micro syringe.

\section{Results and Discussion}

Cytosolic ME convert L-malate into pyruvate with reduction of $\mathrm{NADP}^{+}$into $\mathrm{NADPH}^{+}$, and generated $\mathrm{NADPH}^{+}$is used in lypogenesis along with PPP's $\mathrm{NADPH}^{+}$pool. In the following sections, we have discussed the confirmation of $\mathrm{NADP}^{+}$dependent cytosolic malic enzyme, present in RMIIPL32 and correlated its role in lipid production.

\section{Effect of sesamol for production of lipid and malic enzyme}

RMIIPL32 produced $8.3 \mathrm{~g} / \mathrm{L}$ yeast biomass during growth, with $\mathrm{Yx} / \mathrm{S}=0.415$ and an overall lipid content of $0.30 \mathrm{~g} / \mathrm{L}$ in $24 \mathrm{~h}$. Increase in $\mathrm{C} / \mathrm{N}$ ratio after growth phase, resulted in total non-polar lipid accumulation of $3 \mathrm{~g} / \mathrm{L}$ within next $28 \mathrm{~h}$ with $\sim 80 \%$ consumption of sugar. Lipid accumulation improved with increase in $\mathrm{RM}_{M E}$ activity over the entire fermentation cycle. Lipid yield during maturation phase was $0.21 \mathrm{~g} / \mathrm{g}$ of dry cell biomass (Figure 2) corresponding to maximum $\mathrm{RM}_{M E}$ activity of 0.012 U.mg-1. Fatty acid profiles depicted presence of higher monounsaturated fatty acids (MUFA) namely palmitoleate and oleate along with highest content of Saturated Fatty Acids (SFA) namely palmitate and stearate and absence of Poly Unsaturated Fatty Acids (PUFA). Such composition would lead to a fuel with better cetane number, high Cold Filter Plugging Point (CFPP) and oxidative stability (Table 1) [13]. Sesamol affected cytosolic ME activity and inhibit cell growth and lipid biosynthesis in RMIIPL32. Sesamol was added at the onset of lipid maturation phase, along with concentrated sugar solution to determine its effect in $\mathrm{RM}_{M E}$ activity and lipid yield under nitrogen depleted condition. Overall lipid content was reduced by $64.32 \%$, with inclusion of the inhibitor even at low concentration $(5 \mathrm{mM})$ with $\sim 50 \%$ attenuation in $\mathrm{RM}_{M E}$ activity. Sesamol was proposed to produce catechol like compound by undergoing the removal of its methylene carbon [14]. This imparted its inhibitory effect to ME and thereby decreased fatty acid accumulation through limited NADPH supply. Apart from drastic change in lipid quantity, fatty acid profiles were also affected. Absence of MUFA downgraded the fuel properties. Further increase in sesamol concentration completely abolished $\mathrm{RM}_{M E}$ activity with minimum lipid production ( 1 to $2 \% \mathrm{w} / \mathrm{w}$ cell lipid) that ensured cell survival. Increase in yeast biomass during the maturation phase was primarily attributed to cell biomass generation. Similar profile was depicted in case of catechol based lipid maturation, where negligible fatty acids were reflected in GC $\times$ GC. Inhibitions in lipid production were reported in $R$. toruloides, $C$. utilis and $S$. cerevisae, when sesamol was used to determine ME activity as well as lipid production in bioreactor [15].

\section{Characterization of $\mathbf{R M}_{M E}$}

$\mathrm{RM}_{M E}$ was purified and characterized in detail. Approximately 23.25-fold purification of crude enzyme was achieved with $~ 13.48 \%$ recovery and specific activity of $0.279 \mathrm{U} / \mathrm{mg}$ proteins (Table 2). Purified enzyme migrated as a single band in gel-electrophoresis $(\mathrm{Mr} \sim 200 \mathrm{kD})$, suggesting its homogeneity (Figure 3). Evans and Ratledge reported ME from Rhodosporidium toruloides CBS14 with a molecular size of 


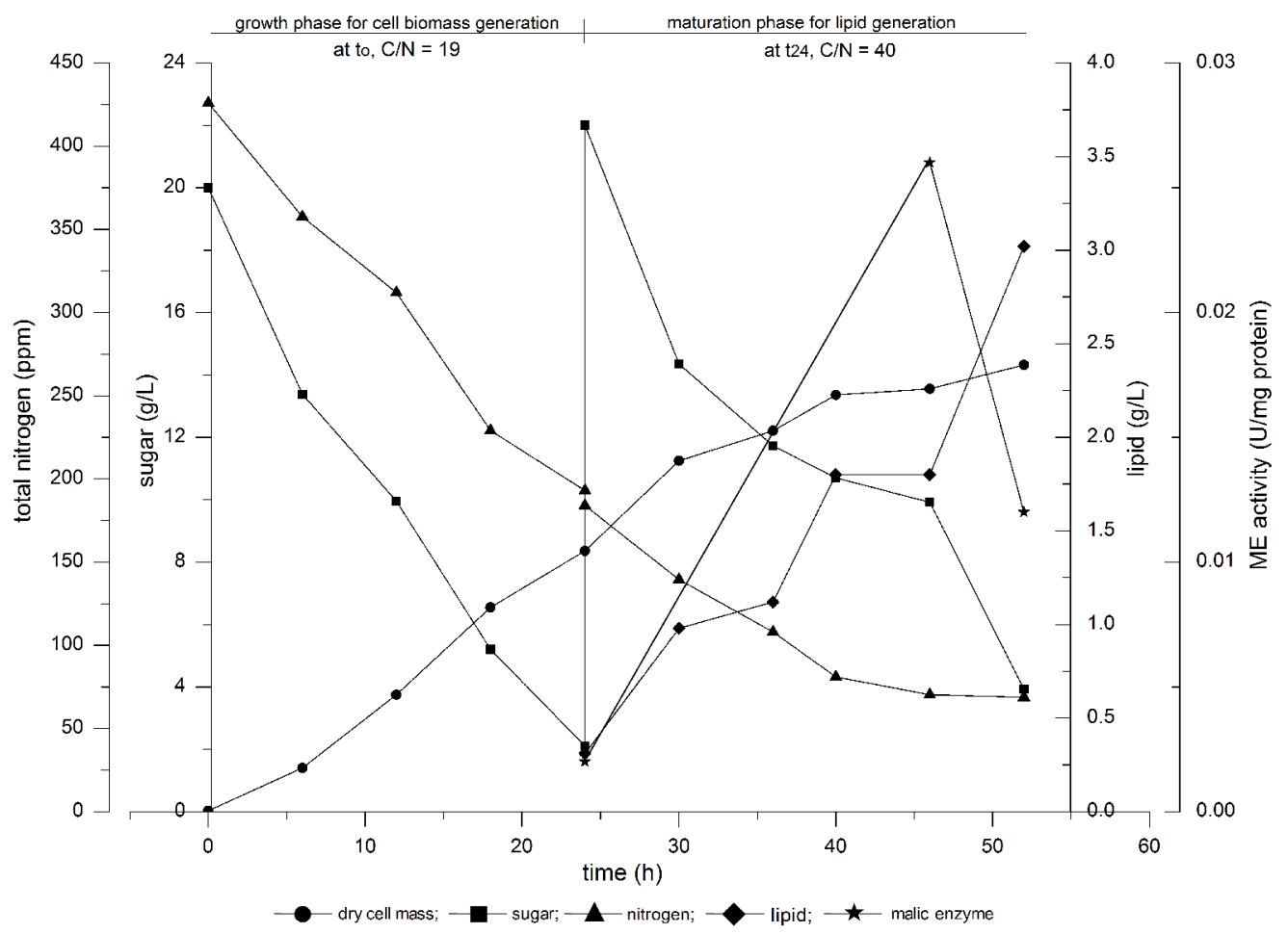

Figure 2: Time course profile of xylose consumption, elemental nitrogen deletion, cell biomass generation, lipid production and RMME activity in fermenter. RMME activity and lipid production were only investigated during lipid maturation phase.

\begin{tabular}{|c|c|c|c|c|c|c|c|c|c|c|c|}
\hline \multirow{2}{*}{ Inhibitor } & \multirow{2}{*}{$\begin{array}{c}\text { Concentration } \\
\mathrm{mM}\end{array}$} & \multirow{2}{*}{$\begin{array}{c}\text { Cell biomass } \\
\Delta \mathbf{g}\end{array}$} & \multirow{2}{*}{$\begin{array}{c}R M_{M E} \\
\text { U.mg-1 protein }\end{array}$} & \multirow{2}{*}{$\begin{array}{c}\text { Lipid yield } \\
\Delta \mathbf{g}^{\prime}\end{array}$} & \multicolumn{7}{|c|}{ Fatty acid profile } \\
\hline & & & & & $\leq C_{6}$ to $\geq C_{14}$ & $C_{16}$ & $C_{16: 1}$ & $\mathrm{C}_{18}$ & $C_{18: 1}$ & $C_{18: 2}$ & $C_{18: 3}$ \\
\hline \multirow{3}{*}{ Sesamol } & 0 & 71.83 & 0.026 & 32.43 & + & ++ & + & ++ & ++ & + & - \\
\hline & 5 & 55.68 & 0.011 & 11.57 & + & + & - & + & - & - & - \\
\hline & 10 & 8.36 & 0 & 1.53 & + & - & - & - & - & - & - \\
\hline Catechol & 10 & 6.82 & 0 & 1.38 & + & - & - & - & - & - & - \\
\hline
\end{tabular}

Table 1: Effects of sesamol and catechol for production of cell biomass, lipid and activity of RMME during lipid maturation phase; $\Delta \mathrm{g}$ and $\Delta \mathrm{g} \square$ indicate difference in cell biomass as well as hexane extracted lipid in grams respectively, between growth phase and maturation phase (up to $80 \%$ consumption of sugar during maturation in 12 $\mathrm{L}$ fermenter batch); during growth phase $99.6 \mathrm{~g}$ cell biomass with $36.3 \mathrm{~g}$ non polar lipids were generated; + indicates presence of fatty acids with corresponding carbon numbers, ++ indicates presence of corresponding fatty acids in higher quantity and-indicates absence of corresponding fatty acids as per GC $\times$ GC.

\begin{tabular}{|c|c|c|c|c|c|}
\hline Purification steps & Total activity (U) & Total protein (mg) & Specific activity (U.mg $\left.{ }^{-1}\right)$ & Purification fold & Recovery (\%) \\
\hline Crude & 11.8 & 999 & 0.012 & 1.00 & 100.000 \\
\hline Cation Exchange Chromatography & 6.3 & 63 & 0.100 & 8.33 & 53.39 \\
\hline Affinity Chromatography & 1.59 & 5.7 & 0.279 & 23.25 & 13.48 \\
\hline
\end{tabular}

Table 2: Summary of results of the purification of the $\mathrm{RM}_{M E}$ from Rhodotorula mucilagenosa IIPL32.

$205 \mathrm{kDa}$ [16]. The molecular weight is in accordance with literature reported purified ME from other microbial origins [17,18]. Song et al. identified 4 isoforms of ME and reported possible role of isoforms III and IV ( $90 \mathrm{kD}$ each) in lipid biosynthesis [19].

$\mathrm{RM}_{M E}$ showed optimal activity at $\mathrm{pH} 7.0$ (Figure $4 \mathrm{a}$ ) and $15^{\circ} \mathrm{C}$ temperature. The $\mathrm{pH}$ profile is similar to the other reported $\mathrm{MEs}$ from human breast cancer cell (7.2), and little lower than that of $M$. alpine (7.5) $[17,20]$. Between $\mathrm{pH} 6.0$ and $8.0, \mathrm{RM}_{M E}$ retained over $50 \%$ of its activity and beyond that a sharp loss in activity was noticed. This might be attributed to changes in protonation state of its active site residues which catalysed the oxidative decarboxylation. Activity of
$\mathrm{RM}_{M E}$ was reduced with lowering of $\mathrm{pH}$, whereas maximum enzyme activity related to lipid production in fermenter was observed at $\mathrm{pH}$ 4.5. Temperature optimum for RMIIPL32 was found to be $32^{\circ} \mathrm{C}$ for maximum cell biomass generation as well as lipid maturation (data not given). However, in vitro, $\mathrm{RM}_{M E}$ was found to be thermolabile. It was most active at $15^{\circ} \mathrm{C}$ upto $90 \mathrm{~min}$, and at $25^{\circ} \mathrm{C}$ it remained stable upto $45 \mathrm{~min}$. Elevation in temperature beyond $25^{\circ} \mathrm{C}$ resulted in marked performance decrease, with no oxidative activity at $55^{\circ} \mathrm{C}$ (Figure $4 \mathrm{~b}$ ). Temperature profiling under different incubation periods demonstrated a typical activity pattern of $\mathrm{RM}_{M E}$. Protein half-life of 45,15 and 5 min were observed with increased incubation temperature of 35,45 and $55^{\circ} \mathrm{C}$ respectively. 


\section{Cofactor specificity and Kinetic determinations}

$\mathrm{RM}_{M E}$ activity was observed with only $\mathrm{NADP}^{+}$as cofactor. A negligible change in absorbance (with L-malate as substrate) was detected when $\mathrm{NADP}^{+}$was replaced by $\mathrm{NAD}^{+}$(Figure 5 ) and confirmed the preference of $\mathrm{NADP}^{+}$over $\mathrm{NAD}^{+}$for oxidatively decarboxylation of L-malate. $\mathrm{K}_{m}$ and $\mathrm{V}_{\max }$ values were determined to be $0.500 \mathrm{mM}$

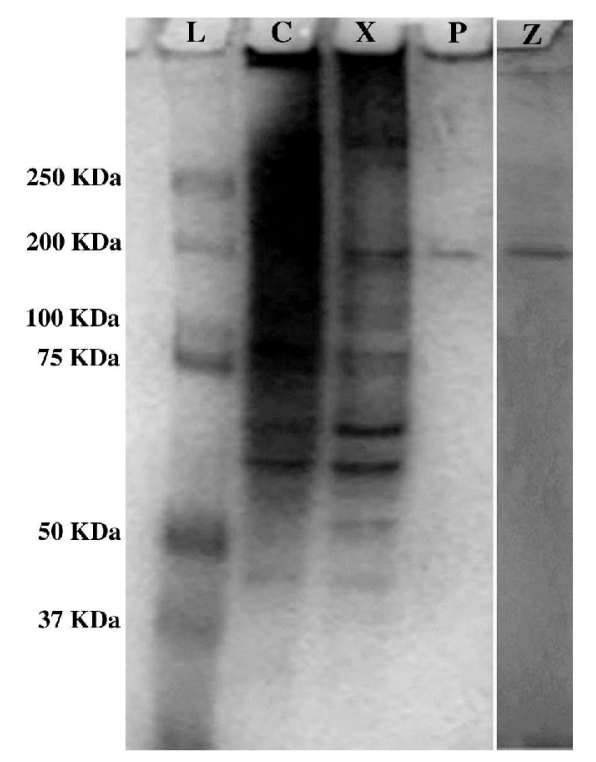

Figure 3: Gel electrophoresis and activity staining of purified RMME (Lane L: Ladder; Lane C: Crude RMME; Lane X: RMME after cation exchange chromatography; Lane P: Purified RMME; Lane Z: Zymogram).

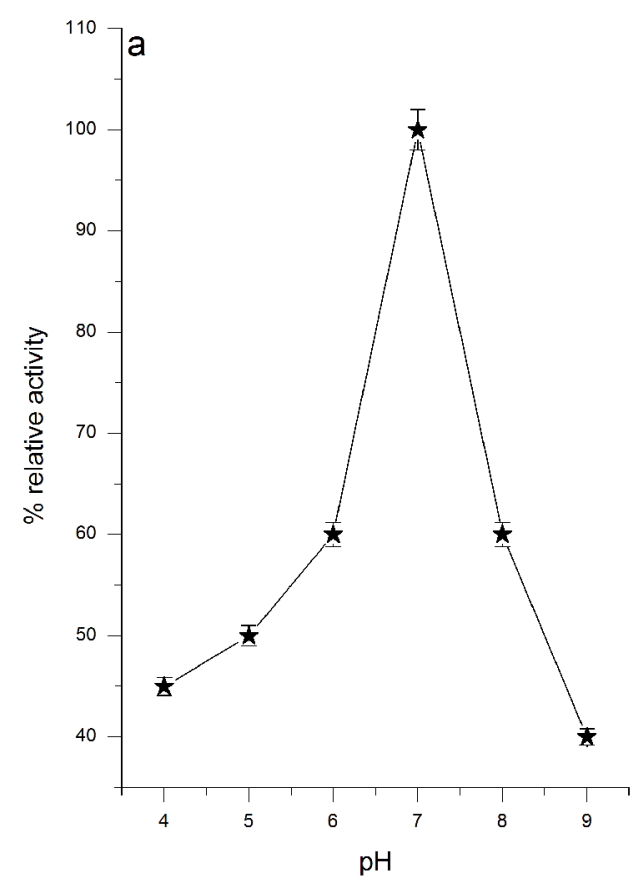

and $0.503(\mathrm{IU} / \mathrm{mg}$ ) respectively for L-malate (Figure 6) and $0.37 \mathrm{mM}$ and 1.13 (IU/mg) respectively for NADP (Figure 6). $\mathrm{K}_{m}$ for L-malate was observed to be in between that of $M$. circinelloides $(0.4 \mathrm{mM})$ and $R$. toruloides $(0.7 \mathrm{mM})$ [16]. $\mathrm{RM}_{M E} \mathrm{~K}_{m}$ for NADP was comparable to that of Mortierella alpina $(0.38 \mathrm{mM})$ and higher than that of Mucor circinelloides $(0.32 \mathrm{mM})[18,19]$. Low $\mathrm{Km}$ value of $\mathrm{RM}_{M E}$ for both L-malate $(0.5 \mathrm{mM})$ and NADP $(0.37 \mathrm{mM})$ confirmed high affinity for the substrate as well as coenzyme, leading to faster $\mathrm{NADPH}^{+}$generation for lipid biosynthesis.

\section{Effects of metal ions}

$\mathrm{RM}_{M E}$ activity was studied on different metal ions as shown in Table 3. Loss of over $50 \%$ activity was depicted with $\mathrm{Zn}^{2+}, \mathrm{Cu}^{2+}, \mathrm{Fe}^{3+}$ and $\mathrm{Ni}^{2+}$, whereas almost complete activity were retained with $\mathrm{Mg}^{2+}$ and $\mathrm{Co}^{2+}$. $\mathrm{Mn}^{2+}$ and $\mathrm{Ca}^{2+}$ enhanced enzyme activity which acted by stabilizing its quaternary structural integrity during catalysis [21]. Pry and Hsu have reported the order of events for pigeon liver $\mathrm{ME}$ wherein $\mathrm{Mn}^{2+}$ binds first, followed by NADP and malate [22]. Metal ion presumably act by polarizing the carboxyl group of the oxaloacetate intermediates during decarboxylation, in agreement with the accepted theory of metal assisted decarboxylation of $\beta$-keto carboxylic acids [23]. $\mathrm{Zn}^{2+}$ strongly suppressed $\sim 65 \% \mathrm{RM}_{M E}$ activity similar to the inhibition reported in Escherichia coli [24]. Divalent $\mathrm{Cu}^{2+}$ has been known to inhibit ME activity and $\mathrm{RM}_{M E}$ activity was decreased by more than $50 \% . \mathrm{Cu}^{2+}$ ions have been purposely, used in Aspergillus niger, where with addition of $\mathrm{Cu}^{2+}$ at the early stage of fermentation to abolish ME activity, was an effective strategy to decrease total lipid [25].

\section{Effects of inhibitors}

Decrease in $\mathrm{RM}_{M E}$ activity in presence of various inhibitors suggested the possible presence of these amino acids in enzyme's active site. Inhibitors effects were investigated on activity of $\mathrm{RM}_{M E}$ to ascertain the string of functional amino acid residues in the catalytic site. Maximum inhibition was obtained with 4-chloromercurobenzoic

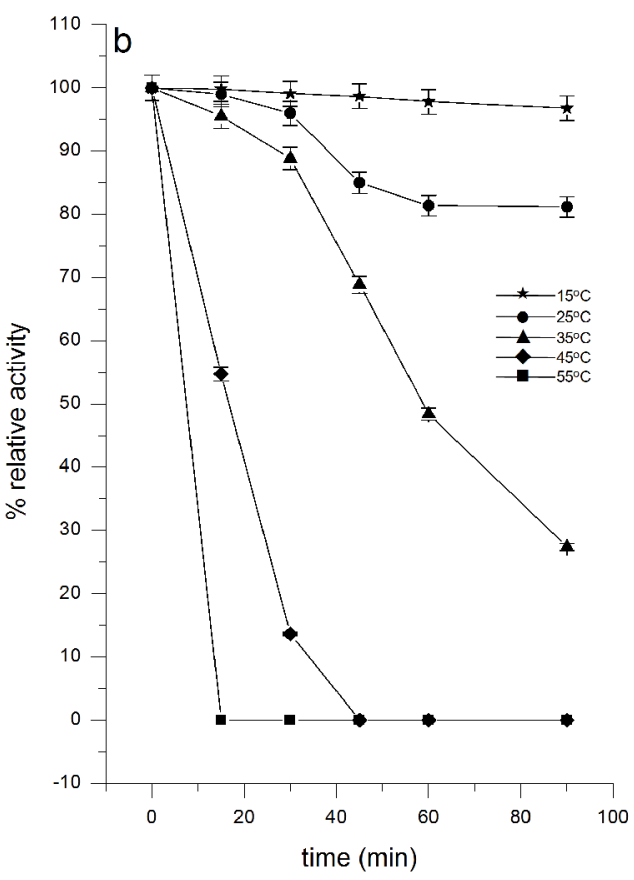

Figure 4: a) Effect of $\mathrm{pH}$ on RMME activity, b) Effect of temperature on RMME stability. 
acid $(22.06 \%)$ which was a circumstantial evidence for the presence of cysteine in the enzyme's active site. The result was in accordance with for duck liver ME, where cysteine played important role in binding of L-malate and divalent metal ions. Pepstatin A (64.15\%), PMSF (66.98\%), iodoacetamide (71.29\%), EDTA (89.11\%), TPCK $(85.85 \%)$

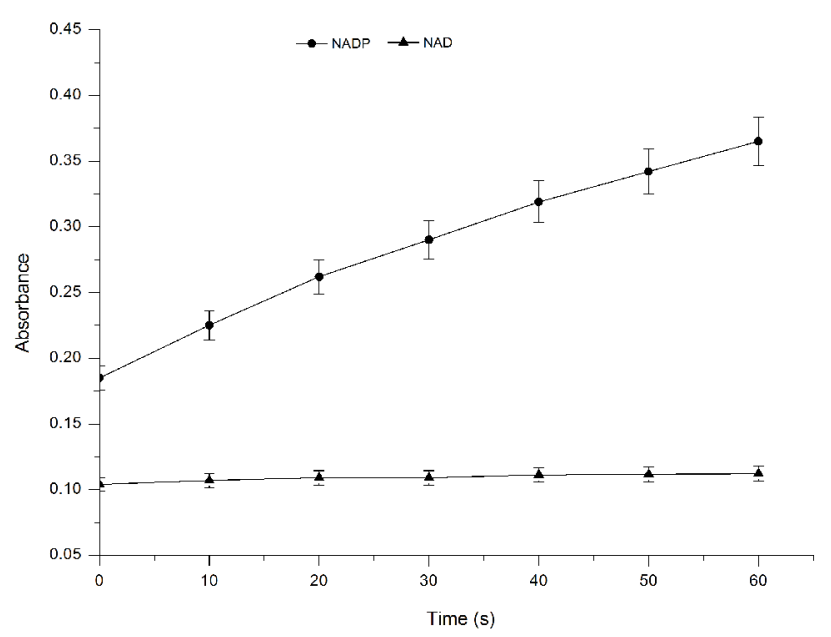

Figure 5: Cofactor specificity for $\mathrm{RM}_{\mathrm{ME}}$. had inhibitory effect for $\mathrm{RM}_{M E}$ activity, while phenylglyoxal hydrate did not inhibit $\mathrm{RM}_{M E}$ [26]. PMSF acts as covalent modifier of serine in proteases. It was concluded that serine might be present in the $\mathrm{RM}_{M E}$ active site and could play a key role in binding of either NADP or the L-malate moiety. TPCK and Pepstatin A were selective for histidine and arginine/aspartate respectively $[27,28]$. Importance of thiol groups for $\mathrm{RM}_{M E}$ activity was confirmed by the inhibitory effect of idoacetamide. In vitro $\mathrm{RM}_{M E}$ was not inhibited by sesamol; rather catechol resulted in $\sim 90 \%$ activity inhibition. Sesamol might be assimilated by RMIIPL32 to yield catechol or similar compounds, which might impart activity inhibition by irreversible binding with $\mathrm{RM}_{M E}$ [14]. This also supported the inhibitory role of sesamol for $\mathrm{RM}_{M E}$ activity and lipid production (Table 4).

\section{Conclusion}

Rhodotorula sp., being non model oleaginous yeast, lack of available genetic information prompted us to investigate the presence and role of cytosolic ME for lipid biosynthesis. Purification and characterization of $\mathrm{RM}_{M E}$ confirmed its cofactor specificity and high affinity for NADP ${ }^{+}$. Correspondingly, RMME activity inhibition by sesamol and catechol established its role in lipid biosynthesis by supplying $\mathrm{NADPH}^{+}$in RMIIPL32. By this study, we conclude that supply of reductants for lipid biosynthesis could be sufficed by $\mathrm{RM}_{M E}$, apart from pentose phosphate pathway in RMIIPL32. Based on fatty acid profile, RMIIPL32 lipid can be transesterified to generate high quality biodiesel.
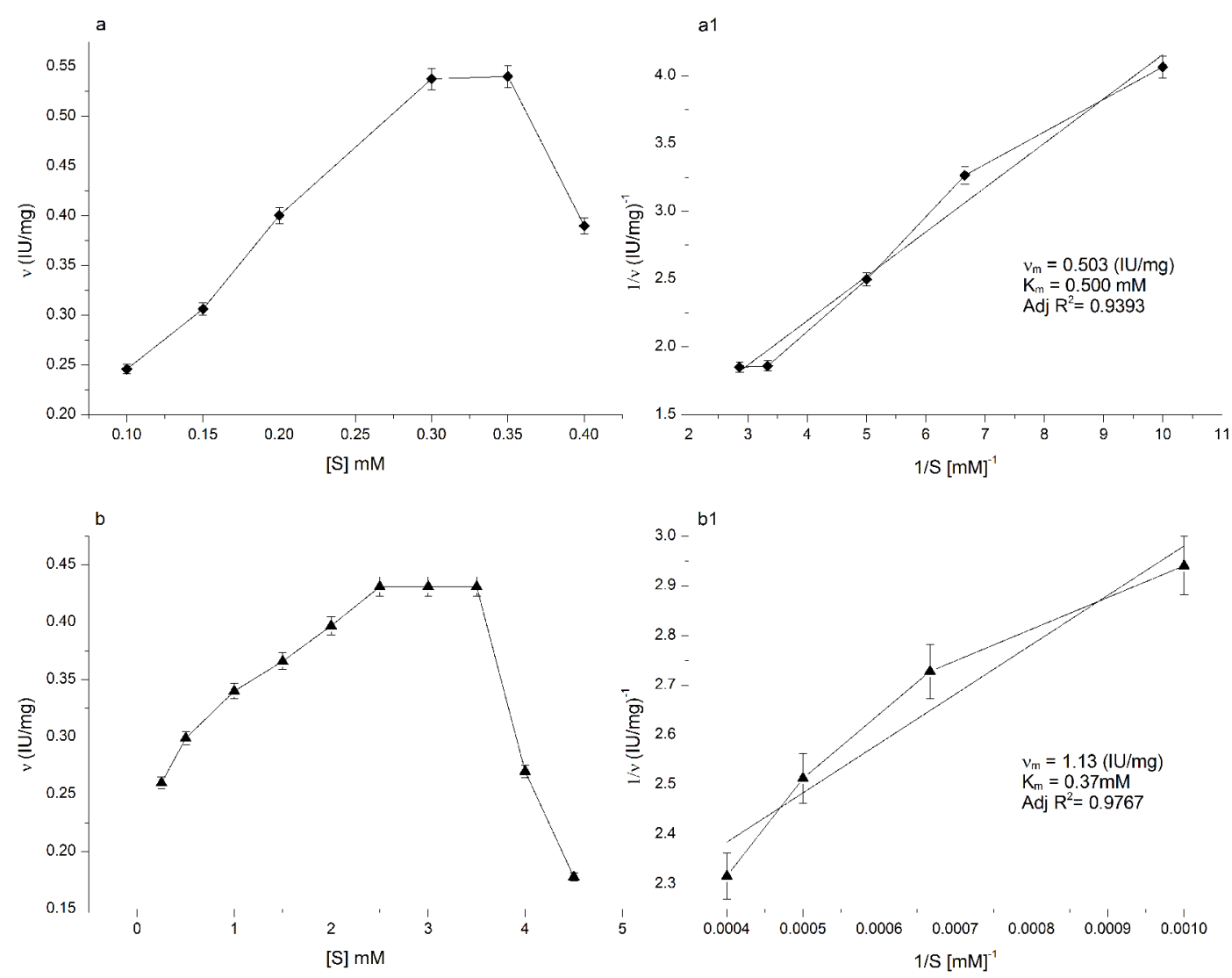

Figure 6: Km determination for RMME varying (a, a1) L-malate (at NADP conc. $1.66 \mathrm{mM}$ ) and (b, b1) NADP (at L-malate conc. $4.16 \mathrm{mM}$ ) using Michaelis-Menten and Lineweaver-Burk plots respectively. 
Citation: Bandhu S, Sharma T, Agrawal D, Ghosh D, Adhikari DK, et al. (2017) Influence of Cytosolic Malic Enzyme in Oleaginous Yeast Rhodotorula mucilaginosa IIPL32 for Lipid Biosynthesis. J Bioanal Biomed 9: 100-106. doi:10.4172/1948-593X.1000161

\begin{tabular}{|c|c|c|}
\hline \multirow{2}{*}{ Metal ions } & Specific activity & Relative activity \\
\cline { 2 - 3 } & U.mg $^{-1}$ protein & $\%$ \\
\hline Control & 0.202 & 100.00 \\
\hline $\mathrm{Mn}^{2+}$ & 0.279 & 138.13 \\
\hline $\mathrm{Mg}^{2+}$ & 0.193 & 95.68 \\
\hline $\mathrm{Ca}^{2+}$ & 0.235 & 116.55 \\
\hline $\mathrm{Co}^{2+}$ & 0.192 & 94.96 \\
\hline $\mathrm{Fe}^{2+}$ & 0.129 & 64.03 \\
\hline $\mathrm{Zn}^{2+}$ & 0.070 & 34.53 \\
\hline $\mathrm{Cu}^{2+}$ & 0.087 & 43.17 \\
\hline $\mathrm{Fe}^{3+}$ & 0.044 & 21.58 \\
\hline $\mathrm{Ni}^{3+}$ & 0.067 & 33.09 \\
\hline
\end{tabular}

Table 3: Effects of metal ions on the activity of $\mathrm{RM}_{M E}$ from Rhodotorula mucilagenosa IIPL32.

\begin{tabular}{|c|c|c|}
\hline \multirow{2}{*}{ Inhibitors } & Specific activity & Relative activity \\
\cline { 2 - 3 } & U.mg $^{-1}$ protein & $\%$ \\
\hline Control & 0.279 & 100 \\
\hline Phenyl glyoxal hydrate & 0.279 & 100 \\
\hline EDTA & 0.249 & 89.11 \\
\hline lodoacetamide & 0.199 & 71.29 \\
\hline TPCK & 0.240 & 85.85 \\
\hline PMSF & 0.187 & 66.98 \\
\hline Pepstatin A & 0.179 & 64.15 \\
\hline Sesamol & 0.062 & 22.06 \\
\hline Catechol & $\mathbf{0 . 2 6 8}$ & $\mathbf{9 6 . 0 5}$ \\
\hline 4-chloromercurobenzoicacid & $\mathbf{0 . 0 4 4}$ & $\mathbf{1 5 . 8 1}$ \\
\hline
\end{tabular}

Table 4: Effects of inhibitors on the activity of $\mathrm{RM}_{M E}$ from Rhodotorula mucilagenosa IIPL32.

\section{Authors' Contributions}

SB, TS, DA, DG and DDG designed overall research plan, study oversight and conducted hands-on experiments with data collection along with drafting of the manuscript; SB and DG had primary responsibility of data representation and final shaping of the manuscript; SB carried Experimental work with TS and DA. DDG and DKA supervised overall work and participated in result interpretation with SB TS and DG; DDG is also the corresponding author. All authors read and approved the final manuscript.

\section{Acknowledgments}

Authors thankfully acknowledge Dr. Anjan Ray, Director, CSIR-IIP, for his constant motivation and support for this study, and for providing necessary infrastructure. Authors also acknowledge CSIR for providing necessary funding through 12 Five Year Plan Project No. CSC-0116/4.

\section{References}

1. Liang MH, Jiang JG (2013) Advancing oleaginous microorganisms to produce lipid via metabolic engineering technology. Progin Lipid Res 52: 395-408.

2. Ratledge C (2014) The role of malic enzyme as the provider of NADPH in oleaginous microorganisms: A reappraisal and unsolved problems. Biotechno Lett 36: 1557-1568.

3. Wynn JP, Hamid AA, Li Y, Ratledge C (2001) Biochemical events leading to the diversion of carbon into storage lipids in the oleaginous fungi Mucor circinelloides and Mortierella alpine. Microbiology 147: 2857-2864.

4. Tang X, Chen H, Chen YQ, Chen W, Garre V, et al. (2015) Complete Genome Sequence of a High Lipid-Producing Strain of Mucor circinelloides WJ11 and Comparative Genome Analysis with a Low Lipid-Producing Strain CBS 277.49. PLoS ONE 10: e0128396.

5. Zhang H, Zhang L, Chen H, Chen YQ, Ratledge C, et al. (2013) Regulatory properties of malic enzyme in the oleaginous yeast, Yarrowia lipolytica, and its non-involvement in lipid accumulation. Biotechnol Lett 35: 2091-2098.

6. Tang W, Zhang S, Tan H, Zhao ZK (2010) Molecular cloning and characterization of a malic enzyme gene from the oleaginous yeast Lipomyces starkeyi. Mo Biotechnol 45: 121-128.
7. Ghosh D, Dasgupta D, Agrawal D, Kaul S, Adhikari DK, et al. (2015) Fuels and chemicals from lignocellulosic biomass: an integrated biorefinery approach. Energ Fuel 29: 3149-3157.

8. Patel A, Pruthi V, Singh RP, Pruthi PA (2015) Synergistic effect of fermentable and non-fermentable carbon sources enhances TAG accumulation in oleaginous yeast Rhodosporidium kratochvilovae HIMPA1. Bioresour Technol 188: $136-144$.

9. Qiguo Y, Jinwen L, Zhifeng W, Jiefei N, Lu M, et al. (2013) Characterization of the NADP-malic enzymes in the woody plant Populus trichocarpa. Mol Biol Rep 40: $1385-1396$.

10. Bradford MM (1976) A rapid and sensitive method for the quantitation of microgram quantities of protein utilizing the principal of protein-dye binding. Anal Biochem 72: 248-254.

11. Hamid AA, Shuib S, Taha EM, Omar O, Khalil MS, et al. (2014) Influence of $\mathrm{N}$-limitation on Malic Enzyme Isoforms and Lipogenesis of Cunninghamella bainieri 2A1. J Teknologi 67: 1-5.

12. Lineweaver $H$, Burk $D(1934)$ The determination of enzyme dissociation constants. J Am Chem Soc 56: 658-66.

13. Jeong GT, Park JH, Park SH (2008) Estimating and improving cold filter plugging points by blending biodiesels with different fatty acid contents. Biotechnol Bioprocess Eng 13: 505-510.

14. Wynn JP, Kendrick A, Ratledge C (1997) Sesamol as an inhibitor of growth and lipid metabolism in Mucor circinelloides via its action on malic enzyme. Lipids 32: 605-610.

15. Li Z, Sun H, Mo X, Li X, Xu B, et al. (2013) Overexpression of malic enzyme (ME) of Mucor circinelloides improved lipid accumulation in engineered Rhodotorulaglutinis. App Microbiol Biotechnol 97: 4927-4936.

16. Evans CT, Ratledge C (1985) Possible regulatory roles of ATP: citrate lyase, malic enzyme, and AMP deaminase in lipid accumulation by Rhodosporidium toruloides CBS 14. Can J Microbiol 31: 1000-1005.

17. Yang J, Hu X, Zhang H, Chen H, Kargbo MR, et al. (2014) Expression, purification, and characterization of $\mathrm{NADP}^{+}$-dependent malic enzyme from the oleaginous fungus Mortierella alpina. Appl Biochem Biotechnol 173: 1849-1857.

18. Hamid AA (2001) Partial purification and malic enzyme studies from Mucor circinelloides and Mortierella alpine. Pak J Biol Sci 4: 277-279.

19. Song Y, Wynn JP, Li Y, Grantham D, Ratledge C (2001) A pre-genetic study of the isoforms of malic enzyme associated with lipid accumulation in Mucor circinelloides. J Microbiol 147: 1507-1515.

20. Chang G, Wang JK, Huang TM, Lee HJ, Chou WY, et al. (1991) Purification and characterization of the cytosolic $\mathrm{NADP}^{+}$-dependent malic enzyme from human breast cancer cell line. Eur J Biochem 202: 681-688.

21. Lianga YJ, Jiang JG (2015) Characterization of malic enzyme and the regulation of its activity and metabolic engineering on lipid production. RSC Adv 5: 45558-45570.

22. Pry TA, Hsu RY (1980) Equilibrium substrate binding studies of malic enzyme of pigeon liver, equivalence of nucleotide sites and anti-cooper activity associated with the binding of L-malate to the enzyme-manganese (II) - reduced nicotinamide adenine dinucleotide phosphate ternary complex. Biochem $\mathrm{J} 19$ 951-962.

23. Wang B, Wang P, Zheng E, Chen X, Zhao H, et al. (2011) Biochemical properties and physiological roles of NADP-dependent malic enzyme in Escherichia coli. J Microbiol 49: 797-802.

24. Wang SW, Mazurkewich S, Kimber MS, Seah SYK (2010) Structural and Kinetic Characterization of 4-Hydroxy-4-methyl-2-oxoglutarate/4-Carboxy-4-hydroxy2-oxoadipate aldolase, a protocatechuate degradation enzyme evolutionarily convergent with the Hpal and DmpG pyruvate aldolases. J Biol Chem 285: 36608-36615.

25. Jernejc K, Legisa M (2002) The influence of metal ions on malic enzyme activity and lipid synthesis in Aspergillus niger. FEMS Microbiol Lett 217: 185-190.

26. Hsu RY, Glynias MJ, Satterlee JD, Feeney R, Clarke AR, et al. (1992) Duck liver 'malic' enzyme Expression in Escherichia coli and characterization of the wildtype enzyme and site-directed mutants. Biochem J 284: 869-876.

27. Sakal E, Applebaum SW, Birk Y (1988) Purification and characterization of Locusta migratoria chymotrypsin. Int J Peptide Protein Res 32: 590-598.

28. Menon V, Rao M (2013) Mechanistic insights into the inhibition of endo- $\beta$ 1,4 xyloglucan hydrolase by a classical aspartic protease inhibitor. J Fluorescence 23: 311-321. 